\title{
УТИЦАЈ ЛЕКСИЧКЕ АНТОНИМИЈЕ НА РАЗВОЈ ТЕРМИНОЛОШКИХ СИНТАГМИ СА КОМПОНЕНТОМ МРТАВ У СРПСКОМЕ ЈЕЗИКУ
}

\begin{abstract}
Предмет истраживања је утицај лексичке антонимије на развој терминолошких синтагми са компонентом мртав. У раду се анализирају синтагме оваквог постања, сагледавају се закони семантичких померања која су синтагме претрпеле, као и улога придевске антонимије у тим померањима. С обзиром на исход семантичке анализе, предлаже се принцип градуелности у приступу терминолошким синтагмама и модификација критеријалног обележја (не)мотивисаности у идентификацији датог типа језичких јединица.

Кључне речи: дијахронијска семантика, терминолошка синтагма, лексичка антонимија, мотивисаност (семантичка прозирност), жив, мртав.
\end{abstract}

\section{1. Предмет истраживања}

1.1. Под термином се у оквирима књижевног (у савременим грађанским друштвима и стандардног) $)^{1}$ језика подразумева „научни или стручни назив, име одређеног појма" (s. v. термин, Клајн/Шипка 2006), тј. термин је реч или синтагма „чији се језички знак поклапа са одговарајућим појмом у појмовном систему дате научне области" (Бјелаковић 2017: 18). ${ }^{2}$

У дијалектологији, историјској фразеологији и сродним дијахронијски усмереним дисциплинама, термин се схвата шире, с обзиром на цивилизацијске оквире етнокултурне заједнице чији се језик изучава, и дефинише се и као народни назив предмета материјалне и духовне културе. Терминолошке

\footnotetext{
*katarina.v.begovic@gmail.com

${ }^{1} \mathrm{O}$ терминима 'књижевни' и 'стандардни језик, као и о разликама међу њима писано је доста (о разликама в. на пример Бугарски 2004: 162-199, Милановић 2010: 11-15, Шипка 1998 : $250-258)$.

${ }^{2} \mathrm{O}$ специфичном семантичком статусу термина у односу на остале јединице општег лексикона в. Гортан Премк ${ }^{2} 2004:$ 116-125; Драгићевић 2007: 20-22; Бјелаковић 2017: 18-19.
} 
синтагме се тако могу одредити као вишелексемни спојеви са функцијом номинације предмета или појава из реалног света (Мршевић Радовић 1987: 21).

1.2. Корпус рада углавном се заснива на вернакулару и критеријум за одабир грађе је лексички - у питању су терминолошке синтагме са компонентама жив и мртав. Основни корпус чини грађа из следећих речника: Даничић 1863-1864, Караџић 1852, RJA, PCA.

Циљ је био истражити укупну грађу терминолошких синтагми кроз време да би се стекао увид у све реализоване начине образовања јединица у континуитету српског језичког израза. Историјски део корпуса је старосрпски, рускословенски и славеносрпски корпус је изузет, а у корпус од Вука надаље укључене су и синтагме из књижевнога језика, пошто законитости лексичке и фразеолошке семантике које одсликавају природу нашега језика морају важити и овде (јединицама из књижевног корпуса приступа се обазриво с обзиром на порекло синтагми и могућности структурно-семантичког калкирања).

1.3. У разматраном корпусу од 31 терминолошке синтагме са компонентом жив, њих девет (29 посто) развија секундарну терминолошку синтагму са опонентом мртав, што чини 33,3 посто од укупног броја забележених синтагми са овим придевом. Овај податак потврђује да је чврста асоцијативна веза међу антонимима важан чинилац у формирању различитих синтагматских структура - од слободних колокација до фразеологизама у ужем смислу (Мршевић Радовић 1987: 57; Дражић 2014: 81).

Одабране терминолошке синтагме

\begin{tabular}{|l|l|}
\hline жива вага & мртва вага \\
\hline жива вакцина & мртва вакцина \\
\hline жива вода & мртва вода \\
\hline живи вулкан & мртви вулкан \\
\hline живи добитак & мртви добитак \\
\hline живи инвентар & мртви инвентар \\
\hline живи језик & мртви језик \\
\hline жива крв & мртва крв \\
\hline жива ограда (живи плот) & мртва ограда \\
\hline
\end{tabular}

1.4. Треба нагласити још нешто. У фразеолошкој литератури се истиче (1) да је једно од обележја терминолошких синтагми немотивисаност (Е. Толикина 1964: 156, према Мршевић Радовић 1987: 21); (2) да између термина и фразеологизама постоје прелазни типови, мотивисани термини (који последично представљају и прелазне категорије од неутралности до експресивности, нпр. народна имена биљака) (Мокијенко 1989: 219-220). Међутим, мотивисани термини не морају бити и експресивни (уп. термине текућа и стајаћа или слана и слатка вода), а семантичка прозирност не чини термине „мање” терминима, напротив - у актуелној терминолошкој литерату- 
ри идеалним се сматра семантички прозиран термин (што не значи да такав мора и бити) (Бјелаковић 2017: 19). Граница између семантички прозирних и непрозирних језичких јединица ,nikako se ne može oštro postaviti, budući da priroda njihove suprotnosti nije binarna, nego skalarna" (Прћић 2008: 93). Аутор даље закључује да је ,gradijentnost [...] ovde inherentno povezana sa protokom vremena" (ibid.), односно са застаревањем - за категорију мотивисаности пресудно је актуелно језичко осећање.

\section{2. Терминолошке синтагме и лексичка антонимија}

Придеви жив и мртав су прави антоними, супротстављена су им примарна значења и семантички се саодносе (Драгићевић 2007: 266-267). Придев жив је немаркирани члан антонимског пара - означава присуство особине. Ова особина '+' чини га семантички доминантним, тј. жив има и номинално и контрастно значење, док мртав има само контрастно. Придеви имају развијену полисемантичку структуру (према РСА, жив има 16, а мртав 15 значења) и супротстављена су им многа, али не и сва секундарна значења, што их чини непуним антонимима (Драгићевић 2007: 268). Поредећи значењске структуре придева закључујемо да секундарна значења немаркираног придева жив углавном прати његов антоним (Ивић 1995: 306) - чак 12 секундарних значења придева мртав настало је аналогијом.

С обзиром на семантичку доминантност немаркираног члана антонимског пара и способност и извесност маркираног члана да секундарна значења развија аналогијом према полисемантичкој структури доминантног антонима, хтели смо да испитамо да ли је (1) импулс за развој терминолошке синтагме кренуо од синтагми са придевом жив; (2) придевска антонимска релација доминантна у терминима чија су значења настала лексичким слагањем одговарајућих значења лексема саставница; (3) антонимија нарушена у примерима у којима долази до семантичке транспозиције целе базне синтагме.

3.1. Секундарно значење придева жив 'активан'3

3.1.1. Метафоричко значење придева жив 'активан' јавља се у RJA са потврдама од 15 . века, а различити примери у речнику јесу у вези са текућом водом:

(1) „Svi, koji žednite ... hodi se napite studenca živoga. M. Držić 437” (16. век) $)^{4}$;

(2) „Rijeka gdi je živa. Vetranić 1, 352” (16. век) (s. v. živ, RJA).

\footnotetext{
${ }^{3}$ У одабраним синтагмама нису посведочени примери са примарним значењем придева жив.

${ }^{4}$ Све потврде из RJA хронолошки су одређене према Popisu kǹiga i rukopisa upotreblenih za rječnik (RJA 23/3: 933-957). Године за потврде из Даничићевог речника дате су према подацима у Monumenta serbica (1858) Ф. Миклошича.
} 
Синтагма жива вода $a^{5}$ има статус термина у народном језику и означава текућу воду. Мотивна је за антонимну синтагму мртва вода у значењу стајаће, непокретне воде:

(3) „Govori se ... voda živa ona, koja izvira, jere se miče, a ona od blata zove se mrtva, jere se ne miče. I. T. Mrnavić istum.” (17. век) (s. v. mr$\operatorname{tav}, \mathrm{RJA}){ }^{6}$

Синтагме успостављају антонимски однос јер немаркирани антоним мртав секундарно значење развија аналогијом према секундарном значењу придева жив (s. v. жив - 6, мртав - 5, РСА). С обзиром на то да су синтагме у језичком осећању биле мотивисане, користиле су се и у експресивном метафоричком значењу (искуство нас учи томе да је текућа вода бистра и чиста, а стајаћа мутна и прљава):

(4) „Od čistoće ja vir živi, ti od gnusobe mrtvo blato. I. Gundulić 249” (17. век) (s. v. mrtav, RJA).

Данас се углавном доживљавају архаичнима и немотивисанима. ${ }^{7}$

3.1.2. Истог постанка и исте семантичке категорије као жива и мртва вода јесу синтагме живи (активни) и мртви (угашени, неактивни) вулкан (уп. симетрична придевска значења s. v. жив - 2. б, мртав - 4. a, PCA):

(1) „Тих вулкана има 'живих' и 'мртвих' т.j. неки још и данас бацају огањ, а други су већ угасили (Радић А., Дом 1900, 156)" (s. v. жив, PCA).

Синтагме знају за варијантност, прозирне су и актуелне, са тим да варијанте са компонентама жив и мртав припадају разговорном језику (на то упућују наводници у примеру из РСА).

Оба синтагматска пара сврставају се у географске термине.

3.2. Секундарно значење придева 'који се састоји од живог'

Ово придевско значење је општесловенско, семантички блиско примарном значењу јер је од њега изведено метонимијски, и последично се налази у истом домену са њим. Најстарији примери у вези са овим значењем у корпусу су из 13. века (s. v. dobitak, RJA).

3.2.1. Жив 'који се састоји од живог' + примарно значење именице

3.2.1.1. Синтагма жива ограда (живи плот) у RJA (s. v. živ) дефинише се као ,živa ograda, živi plot, živa živica, t. j. od grmḷa zasađenog”:

(1) „Živim plotom i dračama vrto i lire svoje gradu. Kavańin (1913) 360" (поч. 18. века);

(2) „А ја наставим пут кући ... путем који је био обрастао с обје стране живим плотом (драчом и купином) (ГЦ 1885, 363)" (s. v. жив, РСА).

\footnotetext{
${ }^{5}$ Синтагме жива и мртва вода које се јављају у општесловенском корпусу бајки анализиране су у Беговић 2019: 142-144.

${ }^{6}$ Историјски примарно значење лексеме блато јесте 'бара', 'jезеро' (s. v. blato, RJA).

${ }^{7}$ Да бисмо стекли увид у категорију мотивисаности анализираних синтагми у актуелном језичком осећању, направили смо анкету са 50 испитаника. Двадесет посто испитаника препознаје наведено значење синтагме жива вода, док 15 посто препознаје значење антонимне синтагме.
} 
Секундарно значење придева жив 'који се састоји од живог' (s. v. жив 3, РСА) са лексемом ограда 8 индукује употребу придевског антонима мртав у значењу 'нежив' (s. v. мртав - 3. а, РCA). За разлику од термина жива ограда, који је актуелан, мртва ограда данас застарева ${ }^{9}$ и посведочена је само у RJA (s. v. mrtav):

(3) „Ovakva sigurnost more se dobiti ili s živom ili mrtvom ogradom ili plotom $[\ldots] "$.

Антонимски однос није симетричан (уп. и синтагме са именичким центрима добитак, инвентар) - супротни однос не успоставља се аналошки насталим значењем антонима према датом секундарном значењу придева жив, већ у однос антонимије ступају различита секундарна значења придева: жив са метонимијски изведеним значењем 'који се састоји од живог' : мртав са метафорички изведеним значењем 'нежив'.

Категорија 'мртав' подразумева чланове који су били живи, а категорија 'нежив' чланове који не могу припадати категорији 'живог'. Лексикализацијом датих категорија придеви жив и мртав односе се на исту категорију денотата, а жив и нежив на различиту. ${ }^{10}$ Синтагме жива и мртва ограда захваљујући метафорички изведеном значењу придева мртав означавају различите категорије денотата (ограда може бити од биљака, али може бити и дрвена, камена итд.).

Што се тиче варијантности термина осим употребе неправих именичких синонима, живица је синоним живој огради и „резултат је тежње ка рационализацији језичког материјала” (Ћорић 2008: 161). ${ }^{11}$

3.2.1.2. Термине жива и мртва вакцина не бележе лексикографски извори. Синтагме су новијег постања, интернационалне (уп. фр. vaccins vivants atténués и vaccins inactivés ou inertes и енгл. live-attenuated vaccines и inactivated (killed) vaccines) ${ }^{12}$, мотивисане су и припадају медицинској терминологији. И у српскоме језику знају за варијантност (жива је атенуирана или жива атенуирана, а мртва је још инактивисана вакцина). Последица су структурно-семантичког калкирања. У српскоме језику синтагме развијају однос неправе, али симетричне антонимије - живе су вакцине оне које се састоје од живих (али ослабљених), а мртве оне које се састоје од мртвих микроорганизама. Придев мртав према секундарном значењу придева жив

\footnotetext{
${ }^{8}$ Именица плот већ означава мртву ограду, то је „ограда од прошћа, летава, дасака, сплетеног прућа, тараба" (s. v. плот, РМС).

${ }^{9}$ Синтагма мртва ограда је семантички прозирна за 20 посто испитаника.

${ }^{10}$ Сам придев нежив посведочен је тек од 17. века у RJA (s. v. neživ) и не реконструише се у ЭССЯ. Нема развијену полисемантичку структуру и сва његова значења настала су аналогијом према значењима придева жив, укључујући и примарно, о чему сведочи и творбени поступак.

${ }^{11}$ Историја терминолошке синтагме и њеног универба живиц̧а показује да живица или жива ограда нису увек биле култивисана ограда, „од грмља сађеног”, већ природна, дивља међа, трњак (s. v. živica - b. „živi plot, ograda od drače, trńa; trńak, ivica”, RJA). С временом се значење модификовало и данас углавном означава култивисану ограду.

12 УП. податке на https://professionnels.vaccination-info-service.fr; https://www.vaccines.gov; https://www.creative-biolabs.com; последњи пут приступљено 3. 3. 2021.
} 
аналошки развија значење 'који се састоји од мртвог' (значење је само контекстуално, не бележе га речници).

3.2.2. Жив 'који се састоји од живог' + историјски примарно и секундарно значење именице

Лексема добитак развија различита значења у старосрпском језику (s. v. dobitak, RJA), са тим да је значења 'посед' (историјски примарно) и 'стока' (секундарно) наследила из псл. периода (s. v. *dobitъkъ, ЭССЯ). У старим српским изворима оба значења јављају се од 13. века (s. v. dobitak, RJA; s. v. доқытькь, Даничић 1863), а већ почетком 14. века посведочене су синтагме живи добитак у значењу 'стока' и мртви добитак у значењу 'посед осим стоке':

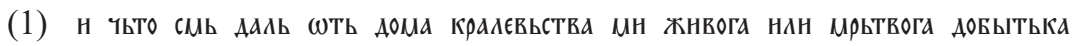
(1302-1321) (s. v. добытькь, Даничић 1863). ${ }^{13}$

Синтагме су посведочене у различитим старосрпским писаним изворима. Резултат су експлициране лексикализације именичких значења придевима жив и мртав. Као резултат, синтагматски пар остварује однос неправе антонимије (придевска семантика је иста као у примеру жива и мртва ограда).

Синтагме су застареле - не препознају се у актуелном језичком осећању, нису забележене у РСА, нити је посведочена лексема добитак са значењима 'посед' и 'стока' (s. v. жив, мртав, добитак, РСАНУ).

3.2.3. Жив 'који се састоји од живог' + секундарно значење именице

Синтагме живи и мртви инвентар јављају се са истим значењем као живи и мртви добитак, а постале су лексичким слагањем секундарног значења придева и именице. Лексема инвентар, пореклом из латинског језика (s. v. инвентар, РСА, РМС, Клајн/Шипка 2006), овде је употребљена у секундарном значењу '(обично покретна) имовина':

(1) „Унео је у задругу сву своју земљу и инвентар. Пол. 1950” (s. v. инвентар, РМС).

Термини су резултат специјализације значења 'имовина' на живу и неживу. Придевска антонимија иста је као у примерима жива и мртва ограда и живи и мртви добитак. Синтагме припадају корпусу савременог књижевног језика (s. v. инвентар, РCA, РМC) и новијег су порекла - са изузетком усамљеног примера у преводном тексту Н. Бијанковића крајем 17. века у RJA (s. v. inventarij), лексема се не јавља у корпусу пре Вука. ${ }^{14}$ Синтагме су данас углавном застареле. ${ }^{15}$

\footnotetext{
${ }^{13}$ У неправом синонимном односу у старосрпском језику са именицом добитак јесте благо, а са синтагмом живи добитак живо благо (s. v. blago - 2. a, b, RJA).

${ }^{14}$ Консултовани су речници довуковске лексикографије из 18. века у којима се могла очекивати лексема инвентар: Орфелинови речници у оквиру уџбеника Латинскій букварь (1766) и Первые начатки латинскаго языка (1767); речник у оквиру граматике С. Вујановског Нгмеикал грамматика (1772); Ръъникъ мальй (1793) С. Лазаревића; речник у оквиру граматике В. Љуштине Грамматіка италіанская (1794).

${ }^{15}$ Синтагме су мотивисане само за десет посто анкетираних.
} 
Термине не бележи корпус књижевнога латинског, француског или италијанског језика, из којих су могли стићи у српски књижевни језик. Међутим, синтагма је посведочена у историјском корпусу немачкога језика од 1860. године, уп.:

(2) „Der Pächter im Nordosten stellt seine und seiner Familie Arbeit, zahlt die indirekten Abgaben und theilt die Ernte mit dem VerPächter, der die Gebäude unterhält, das todte und lebende Inventar liefert und die Grundsteuern entrichtet" (Die Grenzboten. Jg. 19, 1860, I. Semester. I. Band, Korpus Historische Korpora (1465-1969) des Digitalen Wörterbuchs der deutschen Sprache, https://www.dwds.de/d/korpora/dtaxl, претрага према кључним речима lebend Inventar, последњи пут приступљено 3. 3. 2021; курзивом истакла К. Б.).

С обзиром на структурно-семантичке особине синтагми и утицај немачкога језика на српски у датоме хронолошком оквиру, може се претпоставити да су термини калкирани према немачким облицима. ${ }^{16}$

3.3. Секундарно значење придева жив 'који се још употребљава'

Секундарно значење придева жив „који се још употребљава, који има своје носиоце, представнике; који се још негује, чува, одржава" (s. v. жив - 2. в, РСА) настало је од примарног значења придева метафором ЖИВО У ЉУДСКОМ ИСКУСТВУ ЈЕСТЕ ОНО ШТО ЧОВЕК СТВАРА И ОДРЖАВА СВОЈОМ АКТИВНОШЋУ. Ово значење односи се већ од 14. века на сродне појмове из 'језичког' домена (s. v. živ - a. j) govor (jezik, glas, besjeda, riječ), RJA $)^{17}$, а примери употребе у РCA интерпретирају се у терминолошком значењу синтагме живи језик: ${ }^{18}$

(1) „Познавао је готово све мртве и живе европске језике (Бар. 5, 123)” (1954) (s. v. жив, PCA).

Међутим, терминолошко значење синтагме живи језик експлицира семантичку компоненту + 'матерњи говорник'. Ово је сема нижега ранга, имплицирана у хронолошки старијем значењу придева жив 'усмен', јер језик као средство споразумевања прототипично подразумева матерње говорнике. Терминолошко значење настаје перспективизацијом значења придева уз именицу језик истицањем компоненте + 'матерњи говорник'. Синтагма одсликава „процес терминологизације - преласка речи из општег лексичког фонда у неки терминолошки систем” (Бјелаковић 2017: 21). Аналошким развојем семантике придевског антонима (s. v. мртав - 4. в, РСА) формира

\footnotetext{
${ }^{16}$ Синтагме су посведочене само у српскоме књижевном језику у јужнословенском контексту, но, посведочене су и у западнословенским и источнословенским књижевним језицима. Њихово присуство у западнословенском корпусу лако је довести у везу са утицајем немачкога језика, а у источнословенским језицима могле би се довести у везу и са позајмљивањем лексеме инвентар из француског језика и универзалном семантиком придевских компонената.

${ }^{17}$ Поред значења 'усмен' развијају се и значења у вези са последицом употребе усменог језика - 'динамичан', 'делотворан' и сл. (уп. при мере употребе у RJA). У вези са значењем 'динамичан' развијају се у ужем фразеолошком корпусу јединице жива реч и мртво слово на nапиру (в. Мршевић Радовић 2004).

${ }^{18}$ В. одредницу živi jezik у Mozaiku znanja (1972).
} 
се антонимска синтагма мртви језик (- 'матерњи говорник' $)^{19}$ - мртви језик може бити усмен, њиме се може писати, али остаје у лингвистичкој класификацији мртав зато што нема матерњих говорника.

Ови термини су актуелни, припадају књижевним (стандардним) језицима као баштина филологије и лингвистике и интернационални су.

\section{4. Терминолошке синтагме настале сложеном семантичком транспозицијом}

4.1. Синтагме жива вага и мртва вага новијег су постања (s. v. вага, PCA, РМС, Клајн/Шипка 2006). Жива вага се у Речнику САНУ дефинише као „тежина живих животиња (при одређивању њихове цене)”, а мртва као „тежина свега онога што се од заклане животиње може употребити”, уп. пример:

(1) „Мртва вага буше изнашала је 42-45 \% живе ваге (Огризек, ГлМП 1930, 29/29)" (s. v. вага, PCA).

Српска периодика из 19. века сведочи и о синтагмама жива и мртва тежина у истом значењу, уп.:

(2) „Са овим таблицама одређена је сваком говечету како жива, тако и мртва тежина [...]" (Службени војни лист, стр. 5, 15. 10. 1894, http:// www.unilib.rs/istorijske-novine, претрага према кључним речима жива тежина, последњи пут приступљено 3. 3. 2021). ${ }^{20}$

Савремени речници бележе и варијанту жива мера (s. v. мера, PCA) за живу вагу, чиста вага за мртву (s. v. вага, РМС), а чиста тежина се потврђује у корпусу српске периодике (http://www.unilib.rs/istorijske-novine, претрага према кључним речима чиста тежина, последњи пут приступљено 3. 3. 2021).

У савременом језику је најактуелнија варијанта са немачком позајмљеницом, чије је секундарно значење дефинисано као „тежина чега измерена вагањем" (s. v. вага, РМC). Именица у терминолошку синтагму ступа у секундарном значењу, а придев жив доживљава структурно-синтаксичку транспозицију која би се могла представити на следећи начин: вага живе животиње $\rightarrow$ вага живе животиње $\rightarrow$ жива вага. Семантички фокус раскида структурно-семантичку везу конгруентног атрибута и именичког центра унутар падежног атрибута; долази до структурно-семантичке кондензације синтаг-

\footnotetext{
${ }^{19}$ УП. Драгићевић 2007: 274-275.

${ }^{20}$ Синтагма жива тежина (не увек и мртва тежина у датом значењу) посведочена је у великим европским језицима (енглески, немачки, шпански итд.) и у другим словенским језицима. У српском језику може се интерпретирати као језичка универзалија или евентуално калкирање према немачкоме језику - сложеница Lebendgewicht јавља се у немачком корпусу од 1864. године (Korpus Historische Korpora (1465-1969) des Digitalen Wörterbuchs der deutschen Sprache, https://www.dwds.de/d/korpora/dtaxl, претрага према кључној речи Lebendgewicht, последњи пут приступљено 3. 3. 2021).
} 
ме. ${ }^{21}$ Синтагма се обично употребљава у блокираном партитивном генитиву (пет килограма живе ваге), али корпус сведочи и о другим морфосинтаксичким остварењима термина.

Неправи антоним мртва вага који сведочи о аналошкој структурно-семантичкој промени: тежина мртве и очишћене (припремљене) животиње за даљу употребу $\rightarrow$ тежина мртве и очишћене (припремљене) животиње за даљу употребу $\rightarrow$ мртва вага.

Термин жива вага је семантички прозиран, али његов антоним је мање познат савременим говорницима. ${ }^{22}$

4.2. Многи примери у историјским изворима потврђују секундарна, метонимијски изведена значења именице крв 'окршај, 'борба', 'рањавање', 'убиство' (s. v. krv, RJA). Нарочиту пажњу привлачи дефиниција „8. b. mrtva krv znači ubojstvo, živa ranu", а најстарији пример употребе је из 14. века, исти као код Даничића:

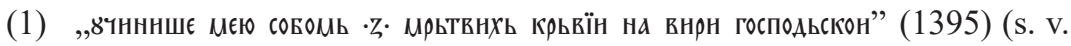
крьвь, Даничић 1863) / „,с̌iniše meju sobomь 7 mrstvihь krьvij na viri gospodbskoj Mon. serb. 226. (1395)” (s. v. krv, PJA3У).

УП. и пример из Poljičkog statuta: ${ }^{23}$

(2) „Ako bi tko učinio krv mrtvu (t. j. ubojstvo) ali živu. (Stat. pol..) Statuta 51 ” (15/16. век) (s. v. živ, RJA).

Према метонимијском моделу ПОСЛЕДИЦА ЗА УЗРОК, крв већ у старосрпском језику значи 'рањавање', 'убиство' и сл.; према Даничићу, најстарија потврда о значењу именице крв 'убиство' јесте из 13. века:

(3) ако крьвь бчннн дьТтнкь, да га пода господарь (1240-1272) (s. v. крьвь, Даничић 1863).

Синтагме су подстакнуте жељом за формалном експликацијом различитих значења лексеме крв (као и у вези са примерима живи и мртви добитак). Жива крв експлицира да човек након рањавања остаје жив, док мртва крв експлицира да је последица напада одузет живот. Семантичка позиција придева̂ је сложена. Они се у контексту остварују у метафоричком значењу мотивисаном метонимијским преносом, у којем се у вези са синтагмом жива крв препознаје и перспективизација. Транспозиција се мора анализирати унутар датог сценарија:

\footnotetext{
${ }^{21}$ Поред поменуте универбизације, у фразеолошкој литератури говори се о кондензацији пословица или устаљених фраза као механизму постанка фразеологизма у ужем смислу (Мршевић Радовић 1987: 62), као и о семантичкој кондензацији фразеологизма до лексичког значења једне од његових лексема саставница - универбизацији унутар ужег фразеолошког корпуса (Валтер/ Мокијенко 2018: 332).

${ }^{22}$ Термин жива вага мотивисан је за 65 посто испитаника, док за мртву вагу зна 20 посто анкетираних.

${ }^{23}$ Језик овога споменика „mješavina je uzmičuće čakavštine i sve raširenije štokavštine [...]” (Poljički statut. Hrvatska enciklopedija, mrežno izdanje, http://www.enciklopedija.hr, последњи пут приступљено 3. 3. 2021).
} 
(1) 'напад' (узрок) $\rightarrow$ 'рањавање' (последица): лексикализација крв / 'рањавање са наглашеном компонентом + 'човек остаје жив': лексикализација жива крв (придев добија метафоричку позицију у функцији конгруентног атрибута);

(2) 'напад' (узрок) $\rightarrow$ 'човек је мртав (смрт)' (последица): лексикализација крв / мртва крв (придев добија метафоричку позицију у функцији конгруентног атрибута).

Синтагме су застареле, не препознају се у актуелном језичком осећању, а РСА чува значења лексеме крв попут 'крвна освета', 'крвава борба, окршај', 'убиство', и сл. (s. v. крв, РСА), али не и терминолошке синтагме.

\section{5. Закључци}

(1) Седам од девет синтагматских парова настало је лексичким слагањем придева и именице у одговарајућем значењу. Најпродуктивније придевско значење јесте 'који се састоји од живог', семантички блиско примарном значењу придева. Придев мртав аналошки прати семантичке позиције доминантног антонима у вези са лексемама вода, вулкан, вакцина, језик, док се асиметрична неправа антонимија 'који се састоји из живог' : 'нежив' успоставља у вези са лексемама ограда, добитак, инвентар.

У примерима у којима је извршена транспозиција целе базне синтагме жива вага : мртва вага, жива крв : мртва крв, такође се успоставља неправа антонимија, што показује доминантност парадигматског односа без обзира на сложене структурно-семантичке преносе које синтагме трпе.

(2) Импулс за формирање антонимне синтагме не полази увек од немаркиране синтагме са антонимом жив - у три случаја (именички центри добитак, инвентар, крв) синтагме настају ради експликације одговарајућих именичких значења.

(3) Механизми развоја лексичких значења са којима придеви улазе у терминолошке синтагме су разнолики: метафора, метонимија, перспективизација, док су сва секундарна значења именица у корпусу метонимијска. Транспозиције целих синтагми заједно са уобичајеним семантичким померањима одликује сложен процес структурно-семантичке кондензације.

(4) Пет од девет анализираних парова зна за варијантност, што показује да нису све терминолошке синтагме устаљене језичке јединице (што би одговарало специфичној семантици термина и његовој функцији), већ да и унутар општег терминолошког система постоји лексичко варирање.

(5) Синтагме се на скали градуелности посматрају од мотивисаних (живи и мртви вулкан, жива ограда, жива и мртва вакцина, живи и мртви језик, жива вага), преко оних које су у процесу застаревања (жива и мртва вода, мртва ограда, живи и мртви инвентар, мртва вага) до застарелих, које се доживљавају као потпуно идиоматизоване (живи и мртви добитак, жива и мртва крв). Анализа показује да за категорију мотивисаности није 
пресудан начин постанка терминолошке синтагме, како би се то могло очекивати. Као општи закључак намеће се то да лексичко слагање не гарантује семантичку прозирност (жива вода), нити да је синтагма настала транспозицијом нужно непрозирна (жива вага) - мотивисаност је пре свега категорија зависна од актуелног језичког осећања говорника.

\section{ИЗВОРИ}

Даничић 1863-1864: Ђуро Даничић, Рјечник из књижевних старина српских, 1-3, Београд: Државна штампарија.

Караџић 1852: Вук Стефановић Караџић, Српски рјечник истумачен њемачкијем и латинскијем ријечима, У Бечу: у штампарији Јерменскога манастира.

Клајн/Шипка 2006: Иван Клајн, Милан Шипка, Велики лексикон страних речи и израза, Нови Сад: Прометеј.

Миклошич 1858: Franz Miklosich, Monumenta serbica spectantia historiae Serbiae, Bosniae, Ragusii, Viennae: Apud Guilelmum Braumüller.

PМC 1967-1976: Речник српскохрватскога књижевног језика, I-VI, Нови Сад: Матица српска.

PCA 1959-: Речник српскохрватског књижевног и народног језика, Београд: CAHУ.

ЭССЯ 1974-: Этимологический словарь славянских языков. Праславянский лексический фонд, Москва: Наука.

Mozaik znanja 1972: Srpskohrvatski jezik, Enciklopedijski leksikon Mozaik znanja, Beograd: Interpres.

RJA 1880-1976: Rječnik hrvatskoga ili srpskoga jezika, I-XXIII, Zagreb: Jugoslavenska akademija znanosti i umjetnosti.

\section{ЕЛЕКТРОНСКИ ИЗВОРИ}

https://www.creative-biolabs.com

https://www.dwds.de

http://www.enciklopedija.hr

https://professionnels.vaccination-info-service.fr

http://www.unilib.rs

https://www.vaccines.gov 


\section{ЛИТЕРАТУРА}

Беговић 2019: Катарина Беговић, Фразеологизми са компонентом жив на српском и јужнословенском говорном простору: дијахронијски и синхронијски аспект, одбрањена докторска дисертација, Филолошки факултет, Београд.

Бјелаковић 2017: Исидора Бјелаковић, Терминологија код Срба у 18. и 19. веку (математичка географија и картографија), Нови Сад: Два пера.

Бугарски 2004: Ranko Bugarski, Jezik u društvu, knjiga 4, Sabrana dela, Beograd: Čigoja štampa.

Валтер/Мокијенко 2018: Harry Walter, Valerij Mokienko, Urslawische Phraseologie: Mythos oder Legende?, Deutsche Beiträge zum 16. Internationalen Slavistenkongress Belgrad 2018 (Herausgegeben von Sebastian Kempgen, Monika Wingender und Ludger Udolph), Wiesbaden: Harrassowitz Verlag, 331-340.

Гортан Премк 22004: Даринка Гортан-Премк, Полисемија и организаиија лексичког система у српскоме језику, Београд: Завод за уџбенике и наставна средства.

Драгићевић 2007: Рајна Драгићевић, Лексикологија српског језика, Београд: Завод за уџбенике.

Дражић 2014: Јасмина Дражић, Лексичке и граматичке колокаиије у српском језику, Нови Сад: Филозофски факултет.

Ивић М. 1995: Milka Ivić, O zelenom konju, Novi lingvistički ogledi, Beograd: Biblioteka XX vek.

Милановић 2010: Александар Милановић, Кратка историја српског књижевног језика, Београд: Завод за уџбенике.

Мокијенко ${ }^{2}$ 1989: Валерий М. Мокиенко, Славянская фразеология, Москва: Высшая школа.

Мршевић Радовић 1987: Драгана Мршевић-Радовић, Фразеолошке глаголско-именичке синтагме у савременом српскохрватском језику, Београд: Филолошки факултет.

Мршевић Радовић 2004: Драгана Мршевић-Радовић, Фразеолошке јединице с компонентом књига, прилог српској лексикографији, Научни састанак слависта у Вукове дане, 32/1, 95-104.

Прћић 2008: Tvrtko Prćić, Semantika i pragmatika reči, Novi Sad: Zmaj.

hорић 2008: Божо Ћорић: Творба именииа у српском језику, Београд: Друштво за српски језик и књижевност Србије.

Шипка 1998: Милан Шипка, Књижевни и/или стандардни језик (прилог појмовно-терминолошком разграничењу), Нам језик, XXXII/3-4, 250-258. 


\title{
Katarina Begovic
}

\section{THE INFLUENCE OF LEXICAL ANTYNOMY IN THE EVOLUTION OF TERMINOLOGICAL SYNTAGMS CONTAINING THE COMPONENT $D E A D$ IN SERBIAN LANGUAGE}

\begin{abstract}
Summary
The subject of this research is the influence of lexical antynomy in the evolution of terminological syntagms that incorporate the element dead. The paper will examine syntagms of such origin, discern the principles of a semantic shift through which the syntagms have undergone and review the role of the adjective antynomy in aforementioned shifting events. In regard to the results of the semantic analysis, the principle of graduality is suggested when approaching terminological syntagms - along with the modification of (non)motivation criteria when identifying the given type of lingual unit.

Key words: diachronic semantics, terminological syntagm, lexical antynomy, motivation (semantic transparency), alive, dead.
\end{abstract}

